\title{
Variable Speed Operation of Turbogenerators to Improve Part-load Efficiency
}

\author{
Dan Li, Roger A. Dougal \\ Department of Electrical Engineering \\ University of South Carolina \\ Columbia, SC, USA \\ lid@email.sc.edu, dougal@cec.sc.edu
}

\author{
Eshwarprasad Thirunavukarasu \\ Department of Mechanical Engineering \\ University of South Carolina \\ Columbia, SC, USA \\ thirunav@email.sc.edu
}

\author{
A. Ouroua \\ University of Texas at Austin \\ Center for Electromechanics \\ Austin, TX, USA
}

\begin{abstract}
Our investigation of variable speed operation of turbogenerators, including both single-shaft and twin-shaft variants, shows significant opportunities to improve part-load efficiency in those certain electrical power generation applications that permit variable speed operation. Efficiency improvement increases as load decreases and the improvement is larger for single-shaft engines than for twin-shaft engines. For example, when operating at $20 \%$ loading, adjusting the engine speed can improve fuel efficiency by $14 \%$ for single-shaft gas turbines, and by $2 \%$ for twin-shaft gas turbines. In addition, we present a semi-theoretical analysis that provides a procedure to obtain the gas turbine optimal efficiency and its corresponding optimal speed as a function of shaft load. Simulation results of part-load variable speed modeling of gas turbines further confirmed the theoretical analysis. This has important practical implications. An analysis of fuel consumption by a gas turbine that operates with a load profile representative of a typical propulsion profile for a DDG51 ship, shows a $15 \%$ reduction in fuel consumption when variable speed operation is used, as compared to fixed speed operation. In addition, the analysis presented in this paper provides a general method to evaluate the steady-state performance of gas turbines operating with variable speed.
\end{abstract}

Index Terms-Fuel consumption, gas turbines, off-design performance, variable speed

\section{NOMENCLATURE}

\begin{tabular}{|l|l|}
\hline$\dot{W}$ & power $(\mathrm{W})$ \\
\hline$\dot{m}$ & mass flow rate $(\mathrm{kg} / \mathrm{s})$ \\
\hline$h$ & enthalpy $(\mathrm{J} / \mathrm{kg})$ \\
\hline$T_{\text {in }}$ & inlet temperature $(\mathrm{K})$ \\
\hline$T_{\text {out }}$ & outlet temperature $(\mathrm{K})$ \\
\hline$\tau$ & torque $(\mathrm{Nm})$ \\
\hline$N$ & speed $(\mathrm{RPM})$ \\
\hline$\omega$ & speed $(\mathrm{rad} / \mathrm{s})$ \\
\hline$\% N$ & relative speed to design speed in map \\
\hline$\eta$ & efficiency \\
\hline$\beta$ & $\begin{array}{l}\text { beta-auxiliary coordinate useful for representing } \\
\text { table format of maps }\end{array}$ \\
\hline$P$ & pressure (Pa) \\
\hline$P L$ & pressure loss percentage \\
\hline$P R$ & pressure ratio \\
\hline
\end{tabular}

This work was supported by the Office of Naval Research under grant N00014-08-1-0080.

\begin{tabular}{|c|c|}
\hline$L$ & load of gas turbine in p.u. \\
\hline$\gamma$ & ratio of specific heat \\
\hline$P_{o}$ & ambient pressure \\
\hline$T_{o}$ & ambient temperature \\
\hline $\mathrm{HV}$ & heating value of fuel $(\mathrm{J} / \mathrm{kg})$ \\
\hline$\theta$ & $\begin{array}{l}\text { temperature correction factor } \\
\theta=\frac{T_{o}}{288.15 K}\end{array}$ \\
\hline$\delta$ & $\begin{array}{l}\text { pressure correction factor } \\
\delta=\frac{P_{o}}{101.325 k P a}\end{array}$ \\
\hline \multicolumn{2}{|c|}{ Subscripts } \\
\hline C & compressor \\
\hline$T$ & turbine \\
\hline C or $T$ & compressor or turbine \\
\hline HT & high pressure turbine (gas generator) \\
\hline LT & low pressure turbine (free power turbine) \\
\hline$l$ & load \\
\hline in & inlet \\
\hline out & outlet \\
\hline$f$ & fuel \\
\hline$c b$ & combustor \\
\hline isen. & isentropic process \\
\hline
\end{tabular}

\section{INTRODUCTION}

GAs turbines are widely used in both mechanical drive applications and electrical power generation as prime movers considering their advantages in weight, compactness, fast response to load changes, and flexibility of fuel choices [1][2][3]. Because of these advantages, gas turbines are largely used in remote and autonomous power plants where space is at premium, by utilities as peak power sources, by the aerospace industry, and in marine applications to power the propulsion system and generate electricity. According to the configuration of the shafts of gas turbines, they are categorized as single-shaft and twin-shaft gas turbines. For single-shaft gas turbine, both the compressor and the turbine share the same shaft as shown in Fig. 1. The twin-shaft gas turbine consists of a single-shaft gas turbine, called the gas generator (or high pressure turbine), driving a free power turbine (or low pressure turbine), as depicted in Fig.2. Single-shaft gas turbines and gas generator sections of twin-shaft turbines may also consist of multiple-shafts forming two or more spools and referred to as multi-spool gas turbines. 


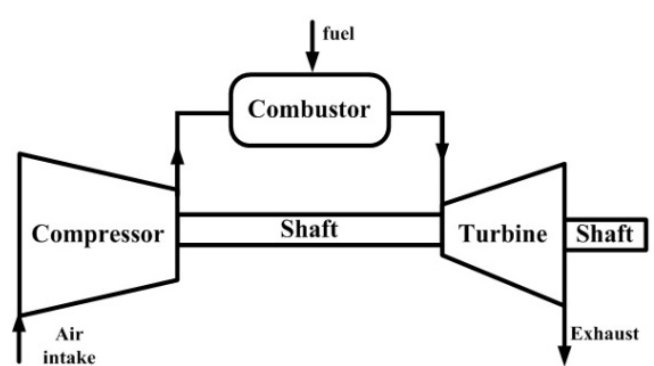

Fig. 1. Diagram of a single-shaft gas turbine

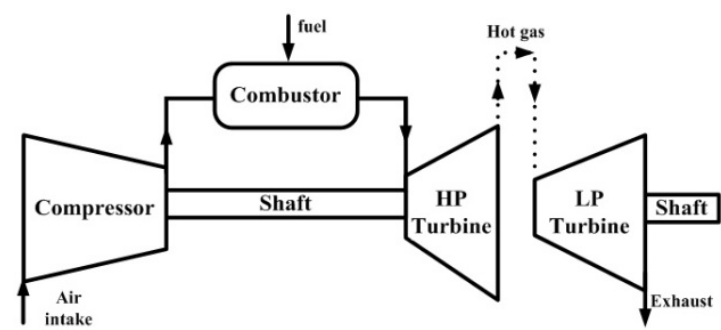

Fig. 2. Diagram of a twin-shaft gas turbine

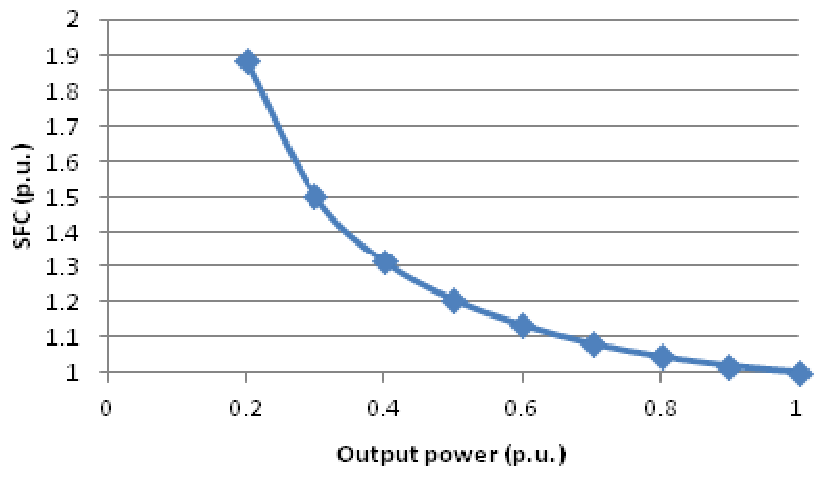

Fig. 3. Typical specific fuel consumption vs. output shaft power for a simple-cycle gas turbine

For electrical power generation, the output shaft typically runs at a fixed speed, the design speed that matches the generator speed to the frequency of the ac distribution system, typically 50 or $60 \mathrm{~Hz}$. Despite the previously mentioned advantages of gas turbines, the well known disadvantage is their low efficiency when operating at part-load [4] [5]. Fig. 3 shows a typical variation of specific fuel consumption (SFC) with turbine output power in p.u. For this particular curve, when the load is $20 \%$ of rated power, the specific fuel consumption is about 1.9 times the rated SFC. However, variable speed operation is emerging as a viable method to improve part-load efficiency, where it has been explored for fuel cell gas turbine hybrid systems [33] [34]. For power generation using turbogenerators, variable speed operation can be realized for both ac and dc systems. In dc systems, a controlled rectifier can maintain the desired dc bus voltage as the speed varies. In ac systems, the desired ac bus voltage can be achieved by the combination of an ac-dc rectifier (either controlled or uncontrolled) with a dc-ac inverter. Of course excitation field control can also be applied in both cases, except in the case of permanent magnet machines. Ref [5] described the part-load efficiency improvement possible for a gearless medium voltage variable speed gas turbine ac system where the desired ac bus voltage was controlled by the inverter only and the rectifier was an uncontrolled diode bridge. That work did not describe modeling of gas turbines, which is critical to understanding and quantifying the variable speed operating mode. We provide a general discussion on this topic in the next paragraph.

An overview of gas turbine models was given in [6] which refers to physical models [14], [16]-[21], time constant-based models [9], IEEE standard models [22][23], aero-derivative models [7], GAST model [24], WECC/GGOV1 model [25][28], CIGRE model [29], and frequency dependent models [30][31]. Physical models derive mathematical equations for each engine stage based on the laws of thermodynamics. Some models, [9], [22], and [23], are accurate only over a very narrow range of speeds and represent only heavy duty gas turbines for power generation. Models of aero-derivative engines, as described in [7], have been developed for twin-shaft gas turbines, but can also be applied to the situation where the speed of the free power turbine is fairly constant. The other models are all similar to the model described in [9] in terms of control schemes, which are all limited to fairly constant speed application too. In the area of gas turbine modeling, a lot of work [7] [8] involves design point modeling [9], which provides mathematical equations for torque, speed, and fuel flow rate near the design operating point. The coefficients of the mathematical equations are tuned based on field measurement data from real gas turbine power plants [8] [10]. There is another approach [11] to develop gas turbine models for both design and offdesign performance analysis. This approach consists of constructing artificial performance maps of compressors and turbines which are constructed from the generalized maps found in the literature [32] with appropriate scaling techniques. Similar to other techniques, it is to be validated with test measurement data from real plants because of the uncertainty in assumptions that are necessarily made to produce the artificial maps. In this work, we used the artificial turbine maps to model the gas turbine in GasTurb [12] to evaluate its off-design performance. We also conducted a semi-theoretical analysis of gas turbine off-design performance with comparison to the modeling and simulation results.

The semi-theoretical analysis of the thermodynamic equations that govern gas turbine engine operation is presented in Section II. This is followed by Section III, a description of the modeling and simulation method and the results therefrom. The torque-speed characteristics resulting from variable speed and fixed speed operations are analyzed in Section IV.

\section{SEMI-THEORETICAL ANALYSIS}

We analyze the gas turbine off-design performance by using basic thermodynamic equations governing gas turbine operation, and typical compressor and turbine characteristic maps. The characteristic maps describe relationships among the pressure ratio, efficiency, mass flow rate, and rotational speed. We used manufacturer's characteristic map data of a particular gas turbine component available from the literature, and scaled it to fit a particular engine configuration [35]. This analysis is termed as semi-theoretical with respect to complete analytical model, since it combines both the characteristic map data and the governing thermodynamic relations. 


\section{A. Assumptions}

In this semi-theoretical analysis, the thermodynamic equations are calculated based on the assumptions below:

- There is no bleed, which means that mass flow consists of air intake at the compressor, fuel input at the combustor, and hot gas exhausts through the exhaust ducts only. . .

- Pressure losses in the compressor, turbine, and ductings are neglected.

- Mechanical losses in pumps and bearings are neglected.

- Pressure loss across the combustion chamber is a constant small percentage of the combustor inlet pressure.

$$
P_{c b-o u t}=P_{c b-i n}\left(1-P L_{c b}\right)
$$

\section{B. Compatibilities of Components and Thermodynamic Equa-} tions

All off-design equilibrium running points are calculated by satisfying the compatibilities of rotational speeds, mass flow, and work among the various gas turbine components as discussed below [14].

Speed Compatibility

For a single shaft gas turbine, the compressor and turbine are directly coupled giving (2):

$$
N_{C}=N_{T}=N_{\text {load }}
$$

For a twin-shaft gas turbine, the compressor is coupled with the gas generator while the free power turbine is connected to the load. The relations are expressed as (3) and (4):

$$
\begin{aligned}
N_{C} & =N_{H T} \\
N_{L T} & =N_{\text {load }}
\end{aligned}
$$

\section{Mass Flow Compatibility}

Without bleed effect, mass flow at the turbine inlet is the sum of compressor outlet air mass flow and fuel mass flow at the combustor as (5):

$$
\dot{m}_{T_{-} \text {inlet }}=\dot{m}_{C_{-} \text {air }}+\dot{m}_{c b_{-} \text {fuel }}
$$

\section{Power Compatibility}

Neglecting loss, the power generated by the turbine is consumed by the compressor and load (6) and (7):

$$
\begin{aligned}
& \dot{W}_{T}=\dot{W}_{c}+\dot{W}_{l} \\
& \dot{W}_{C \text { or } T}=\dot{m}\left(h\left(T_{\text {in_C or } T}\right)-h\left(T_{\text {out_C or } T}\right)\right)
\end{aligned}
$$

The enthalpy value against temperature is available in the literature. In this work, we used the curve fitted correlation of enthalpy and temperature from the software Gas Turb [12] to calculate the enthalpy and power therefrom. The outlet temperatures of compressor and turbine are calculated as (8) and (9)

$$
\begin{gathered}
T_{\text {out }-C}=T_{\text {in_ } C}+\frac{T_{\text {in_ } C}}{\eta_{C, \text { isen }}}\left(P R_{C}^{\frac{\gamma-1}{\gamma}}-1\right) \\
T_{\text {out }-T}=T_{i n_{T}}-T_{\text {in_ } T} * \eta_{T, \text { isen }}\left(1-\left(1 / P R_{T}^{\frac{\gamma-1}{\gamma}}\right)\right)
\end{gathered}
$$

The pressure ratio, mass flow, and efficiency are functions of speed, and auxiliary coordinate $\beta$ [12] as (10) to (12) below. The auxiliary coordinate $\beta$ avoids the ambiguity of vertical and horizontal speed line characteristics representation of the map, and thus better support data retrieval from the map table.

$$
\begin{gathered}
P R_{C \text { or } T}=f_{1}(\beta, \% N) \\
\left(\dot{m} \frac{\sqrt{\theta}}{\delta}\right)_{C \text { or } T}=f_{2}(\beta, \% N) \\
\left(\eta_{\text {isen }}\right)_{C \text { or } T}=f_{3}(\beta, \% N)
\end{gathered}
$$

Where

$$
\begin{aligned}
P R_{C} & =\frac{P_{\text {out_C }}}{P_{\text {in_C }}} \\
P R_{T} & =\frac{P_{\text {in_ } T}}{P_{\text {out_T }}}
\end{aligned}
$$

with the scaling laws (15) to (17) which help to generalize the use of available component maps to different configuration [35]:

$$
\begin{gathered}
P R=\frac{P R_{\text {des }}-1}{P_{\text {map }, \text { des }}-1}\left(P R_{\text {map }}-1\right)+1 \\
\dot{m}=\frac{\dot{m}_{\text {des }}}{\dot{m}_{\text {map,des }}}\left(\dot{m}_{\text {map }}\right) \\
\eta_{\text {isen }}=\frac{\eta_{\text {isen,des }}}{\eta_{\text {isen,map des }}}\left(\eta_{\text {isen,map }}\right)
\end{gathered}
$$

Finally, the gas turbine efficiency and torque are calculated as (18) and (19):

$$
\begin{gathered}
\eta_{f}=\frac{\dot{W}_{T}-\dot{W}_{C}}{\dot{m}_{f} * H V} \\
\tau_{C \text { or } T}=\frac{\dot{W}_{C \text { or } T}}{\omega}
\end{gathered}
$$

An iterative process is needed to solve the governing equations (2) to (19) and follows the procedure for single-shaft gas turbine as below [14]:

- Select a speed line on the compressor.

- The corresponding point on the turbine characteristic is obtained from consideration of compatibility of rotational speed and mass flow.

- With matched compressor and turbine characteristics, check whether the generated work corresponding to the selected operating point is compatible with the required driven load.

For twin-shaft gas turbine, the matching of gas generator and free power turbine is also needed. In this work, we use multivariable Newton Raphson iteration method to do the iterative calculations until an equilibrium running point is found.

\section{Semi-theoretical Results of Single-shaft Gas Turbine}

Using the semi-theoretical analysis method, the above equations were iteratively solved. The analysis investigated a 5.71MW, 15808RPM single-shaft gas turbine. The output data were analyzed and fitted for the optimal efficiency and speed as a function of load.

$$
\begin{aligned}
\eta_{\text {opt-1shaft }}= & 28.06 L^{3}-71.01 L^{2}+64.44 L+12.48 \\
N_{\text {opt-1shaft }}= & 1.4931 L^{4}-4.170 L^{3}+4.0111 L^{2} \\
& -1.3682 L+1.0342
\end{aligned}
$$

These results (dashed lines) are plotted on Fig. 5 for comparison with simulation results. From the plot, we can see that the semi-theoretical analysis results have similar trend as the 
simulation results. The semi-theoretical analysis results were subjected to some modeling assumptions with respect to losses as discussed earlier while the simulation results for this case study considered several important parameters to replicate a gas turbine engine in working environment condition.

The various parameters that were considered in this case study by simulation were bleed, inlet/outlet losses, combustor part load calculation, shaft efficiency, component geometric properties, and other standard loss calculations. This was also the reason behind the curves of semi-theoretical results being on the higher side in Fig. 5. Otherwise, the overall graphical comparison shows an improvement of part-load efficiency for variable speed operation as compared to fixed-speed operation. Further in-depth discussion will be given in the following sections.

\section{Semi-theoretical Results of Twin-shaft Gas Turbine}

Similarly, following the same procedure of solving singleshaft gas turbine, the semi-theoretical results for a $0.96 \mathrm{MW}$ 20000RPM twin-shaft gas turbine are described in terms of optimal efficiency and its corresponding optimal speed as a function of load:

$\begin{aligned} \eta_{\text {opt-2shaft }}= & -13.323 L^{2}+31.1 L+17.372 \\ N_{\text {opt-2shaft }}= & -19.89 L^{4}+54.99 L^{3}-55.1 L^{2} \\ & +24.16 L-2.96\end{aligned}$

These results (dashed lines) are plotted on Fig. 10 for comparison with simulation results. The explanation of the semitheoretical results of single-shaft turbines given earlier also applies to the case of twin shaft engines.

\section{MODELING AND SIMUlation}

The traditional linear modeling of gas turbine [7] [8] [9] are only valid for a small range around the design speed. In addition, modeling parameters are determined from tedious calculations and a tuning process using data obtained from field measurements. To study the wide range of operating speed other than the design speed, as well as part load condition, the gas turbine is modeled in GasTurb to verify the results obtained by the semi-theoretical analysis method described in section III. To determine the maximum efficiency points at different load conditions, from 0.2 to 1.0 p.u. both single-shaft and twin-shaft gas turbines were simulated for a range of shaft speed, 0.8 to 1.2 p.u. with increment of 0.01 p.u.

\section{A. Single-Shaft Gas Turbine Modeling}

Fig. 4 is the model set-up in GasTurb for a 5.71MW, 15808RPM single-shaft gas turbine power generation unit. The simulation results show, the impact of variable speed operation on single-shaft gas turbine efficiency as illustrated in Fig. 5 and Fig. 6. In Fig. 5, the green curve is the optimal speed corresponding to the optimal efficiency as indicated on the figure. The fixed speed efficiency curve is part-load efficiency at design speed, $\mathrm{N}=1.0$ p.u. As can be seen on Fig. 5, for lower power load demand, the gas turbine is more efficient at lower speed, as compared to fixed design speed. For this specific single-shaft gas turbine, the maximum absolute efficiency gain is $2.47 \%$ and its relative efficiency increased $14.77 \%$ at load with 0.2 p.u. where the optimal speed is 0.84 p.u. Because of physi- cal limitations, every gas turbine has its allowable specific operating speed range. For this modeled single-shaft gas turbine, the shaft cannot run at speed lower than 0.84 p.u. which shows up as non-convergences in simulation as indicated in Fig. 7 and Fig. 8. In all compressor and turbine maps, such as those shown on Fig. 7 to Fig. 9, N means speed in p.u.; contours of constant efficiency are indicated with red dotted lines and corresponding numbers The upper red dashed line is the surge line, which confines the feasible engine operating points. Also in Fig. 7 and Fig. 8, the green dot is the design point and the red dot is the operating point at speed of 0.83 p.u. The part-load efficiency improvement would be higher if the compressor had a wider range of operating speeds.
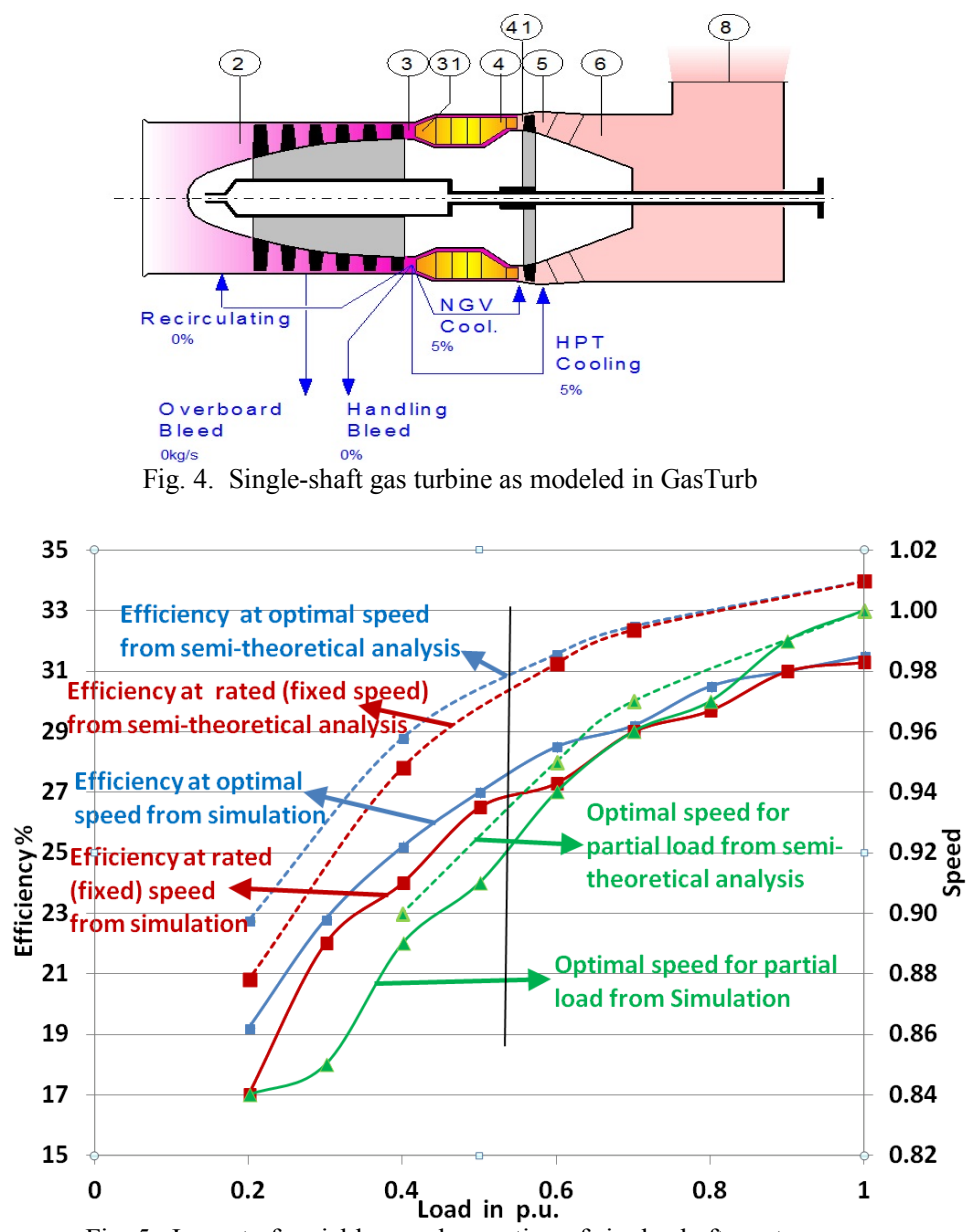

Fig. 5. Impact of variable speed operation of single-shaft gas turbine efficiency

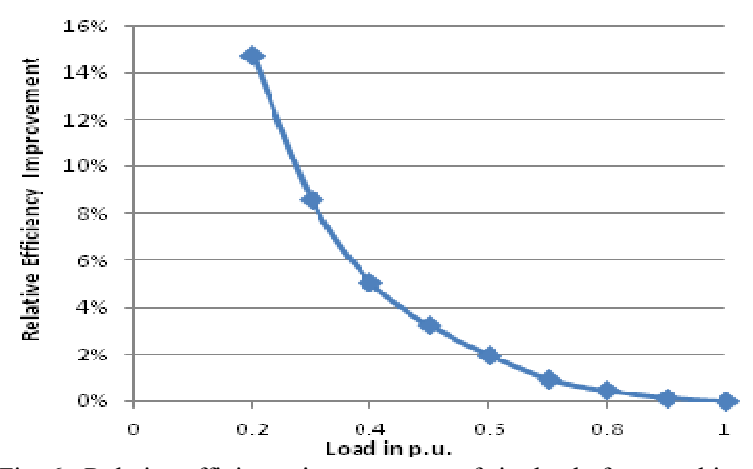

Fig. 6. Relative efficiency improvement of single-shaft gas turbine at variable speed 


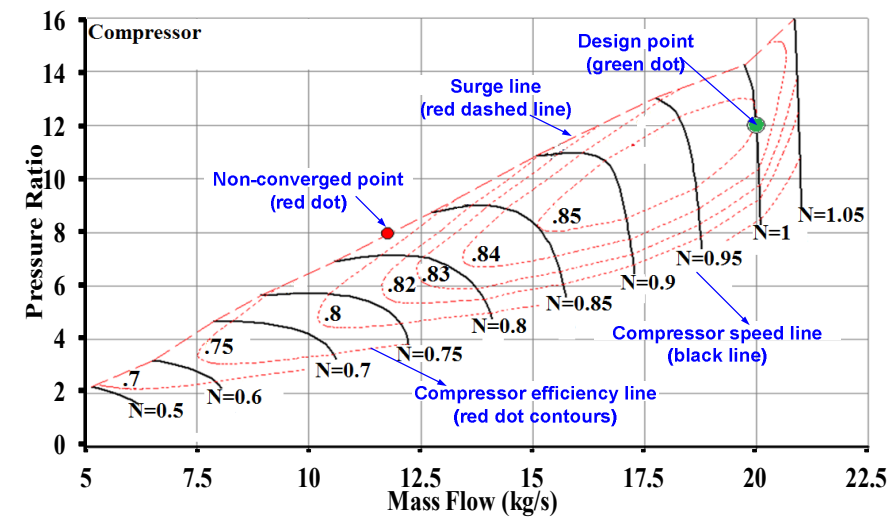

Fig. 7. Compressor operating at speed $\mathrm{N}=0.83$ p.u. in single-shaft gas turbine

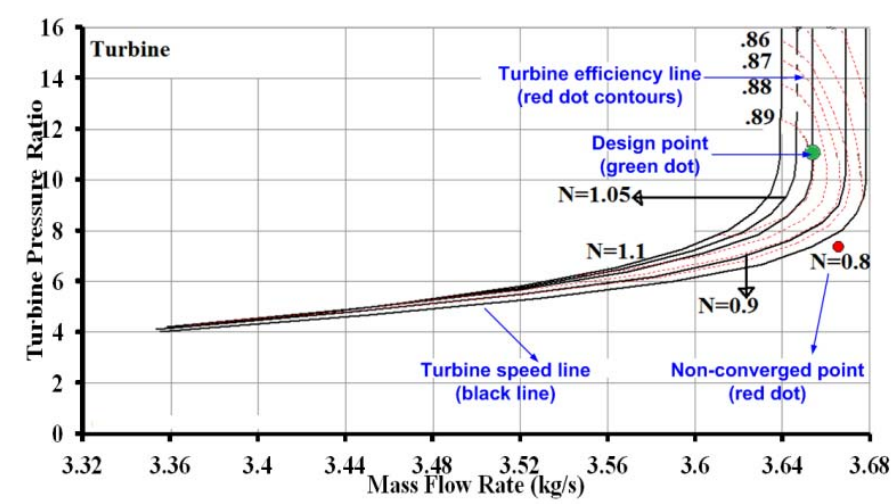

Fig. 8. Turbine operating at speed $\mathrm{N}=0.83$ p.u. in single-shaft gas turbine

Almost two thirds of power generated by the turbine is used by the compressor, and the turbine efficiency is relatively high as compared to the compressor efficiency. Therefore, adjusting the speed of the compressor corresponding to the loading is the key to improve the part-load efficiency of the whole gas turbine. With different load conditions, the efficiency of the compressor running at fixed speed (design speed 1.0 p.u.) decreases along the speed line as can be seen in Fig. 9. But in variable speed operation mode, the compressor efficiency decreases much less compared to fixed speed operating mode as in Fig. 9, where the green dots are the optimal speed operating points and the green dashed line is variable speed operating trend for optimized efficiency when the load decreases.

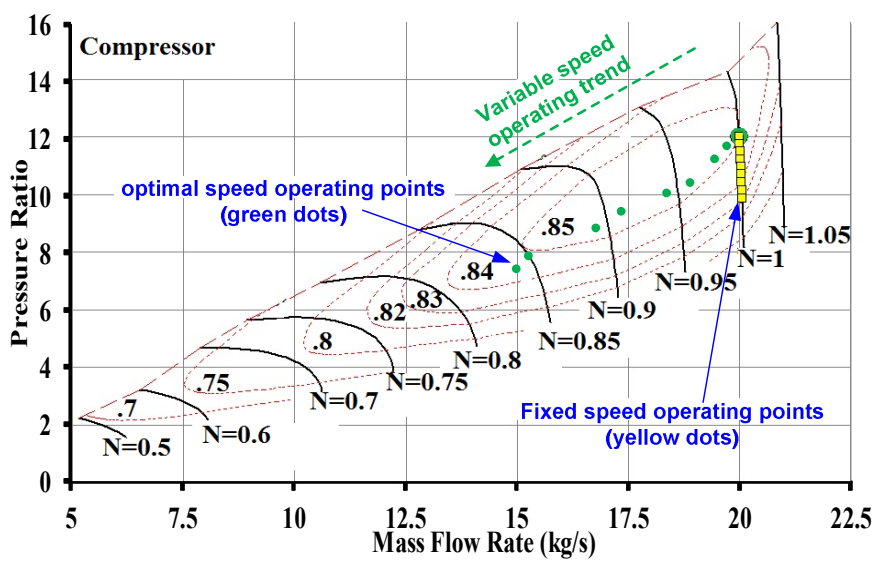

Fig. 9. Compressor part load efficiency at fixed speed $\mathrm{N}=1$ p.u.

\section{B. Twin-Shaft Gas Turbine Modeling}

Similar to the modeling of single-shaft gas turbine, a 0.96MW 20000RPM twin-shaft gas turbine was modeled and variable speed operation of the free power turbine was simulated as well. The impact of variable speed operation on efficiency is illustrated in Fig. 10. Compared to the modeled single-shaft gas turbine feasible operating speed range, from 0.84 to 1.2 p.u. the modeled twin-shaft gas turbine has a wider feasible operating speed range, from 0.8 to 1.2 p.u.

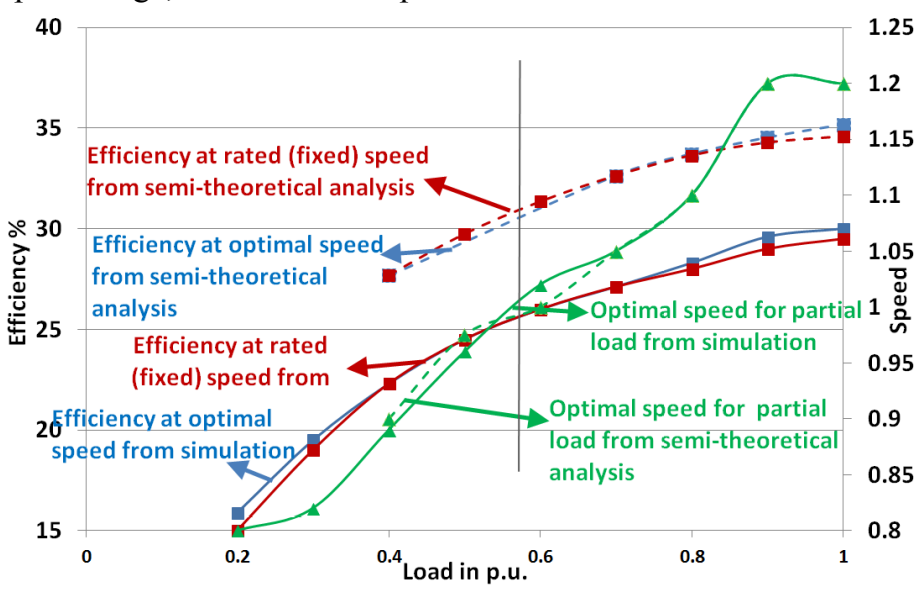

Fig. 10. Impact of variable speed operation of twin-shaft gas turbine efficiency

Fig. 10 shows that the maximum efficiency gain is $0.77 \%$ which increases from $15.03 \%$ to $15.8 \%$ at $20 \%$ of rated load with optimal speed $\mathrm{N}=0.8$ p.u. For this load demand, running at variable speed operation may save up to $5.11 \%$ of fuel consumption. Running the free power turbine at variable speed operation only benefits the free power turbine itself, since the gas generator already runs at variable speed automatically based on the shaft load demand. The small change in efficiency with speed can also be explained by the free turbine powerspeed curve shown in Fig. 11 [14] which exhibits a speed range where power changes very little and which results in a small change in efficiency as well.

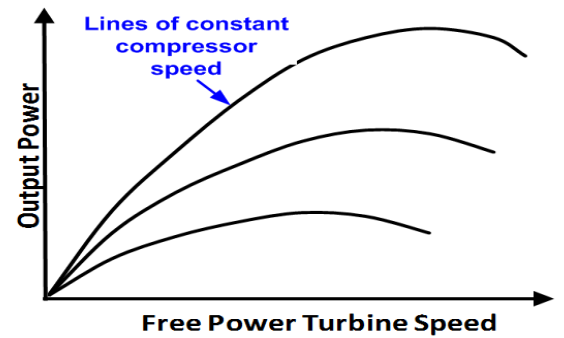

Fig. 11. Impact of variable speed operation of twin-shaft gas turbine efficiency [14]

\section{Test on Given LoAd ProfiLe}

To further quantify the impact of variable speed operation of the single-shaft gas turbine, a load profile that illustrates the inherent part-load characteristics of propulsion in a navy ship is used to calculate total fuel consumption for constant and variable speed operations. Fig. 12 shows a typical speed profile of a DDG51 ship [13] (We use the speed profile as a surrogate for the electric power consumption profile on the basis that the propulsion system consumes the largest fraction of total electric 
power). The corresponding power profile is shown in Fig. 13, in p.u., to illustrate the typical variation of propulsion power with ship speed. While the top speed of 30 knots requires full propulsion power, the time spent at that speed is less than $1 \%$. This indicates that for the majority of the time, propulsion operates at part-load which will have a major impact on fuel consumption, and using variable-speed operation in this case has potential for significant fuel saving. The relationship between the efficiency $\eta$ and the load power $P_{\text {shaft }}$ (p.u.) at fixed speed as in Fig. 5 can be expressed as a polynomial equation with curve fitting

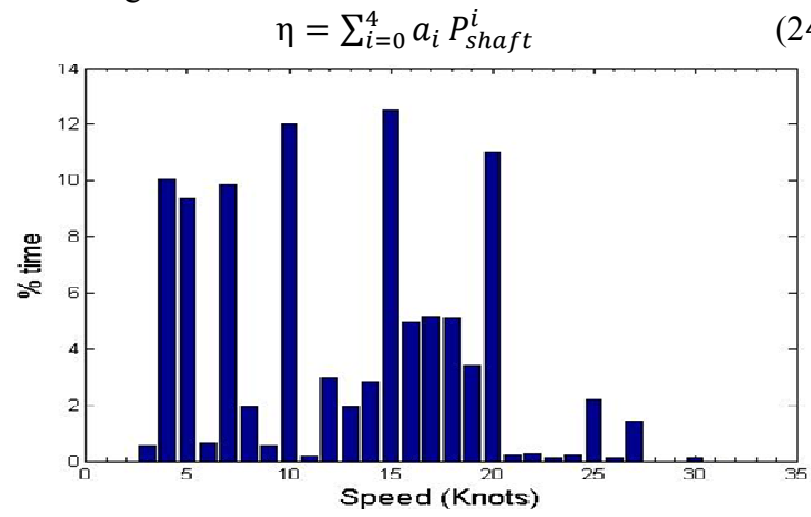

Fig. 12. Typical propulsion speed profile of DDG-51 [13]

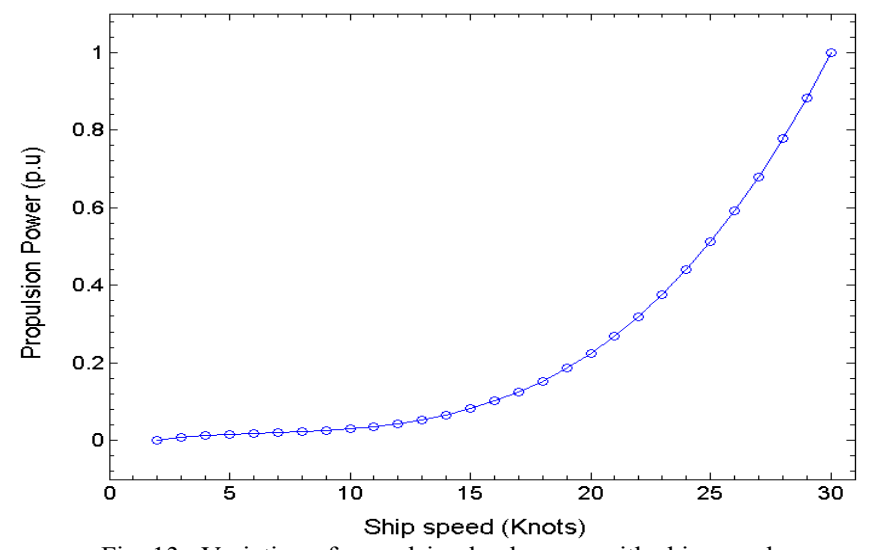

Fig. 13. Variation of propulsion load power with ship speed

By scaling the load profile in Fig. 13 to the rated power of the single-shaft gas turbine studied earlier, i.e. 5.71MW, and by constructing a 24-hour load profile that satisfies the speed and power profile shown in Fig. 12 and Fig. 13, total fuel consumption can be calculated for constant and variable speed operation of the gas turbine. For the load profile given in Fig. 12, the total 1-day fuel consumption at variable speed and fixed speed operations are in Table 1. If a similar load profile was used, but with different power rating, the absolute fuel consumption reduction may be lower, but it is still $15.02 \%$ fuel consumption reduction per day as compared to original fixed speed operation. The results are summarized in Table 1.

Table 1: Example of 1- day fuel consumption for constant and variable speed operation of gas turbine

\begin{tabular}{|c|c|}
\hline Operation Mode & Fuel (kg) \\
\hline Fixed Speed (N=1 p.u.) & $1.32 \mathrm{e} 4$ \\
\hline Variable Speed & $1.12 \mathrm{e} 4$ \\
\hline \multicolumn{2}{|c|}{$\begin{array}{l}\text { Fuel Consumption Reduced: } 15.02 \% \\
(1.98 \mathrm{e} 3 \mathrm{~kg})\end{array}$} \\
\hline
\end{tabular}

The calculation performed here, with a single-shaft gas turbine, was to illustrate the difference in fuel consumption between the two modes of gas turbine operation using a given load power profile that exhibits part-load characteristics as an example. It is important to note that in a typical ship there are several prime movers with different power ratings which can be adjusted so as to minimize fuel consumption when the load changes. In the multiple engines of system, if the number of on-duty turbines and their power sharing are optimized based on the load demand to improve overall system efficiency, then the variable speed operation mode will not bring as much as fuel saving for that in one single engine case. However, if there is redundancy requirement in the system, then the variable speed operation is very beneficial in fuel saving like the investigated single-shaft turbine.

\section{TORQUE CHARACTERISTIC COMPARISON}

The impact of variable speed operation on the torque speed characteristics of single-shaft and the gas generator of twinshaft gas turbines are described in Fig. 14 and Fig. 15.

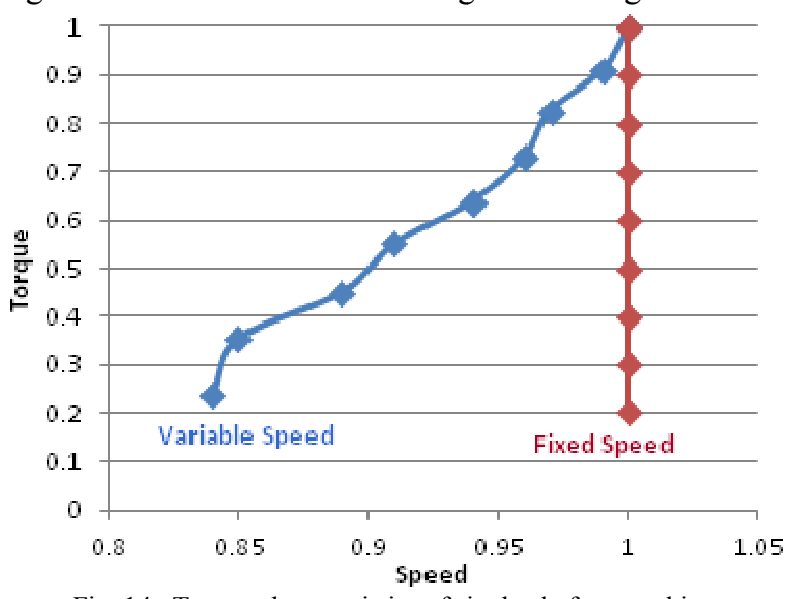

Fig. 14. Torque characteristics of single-shaft gas turbine

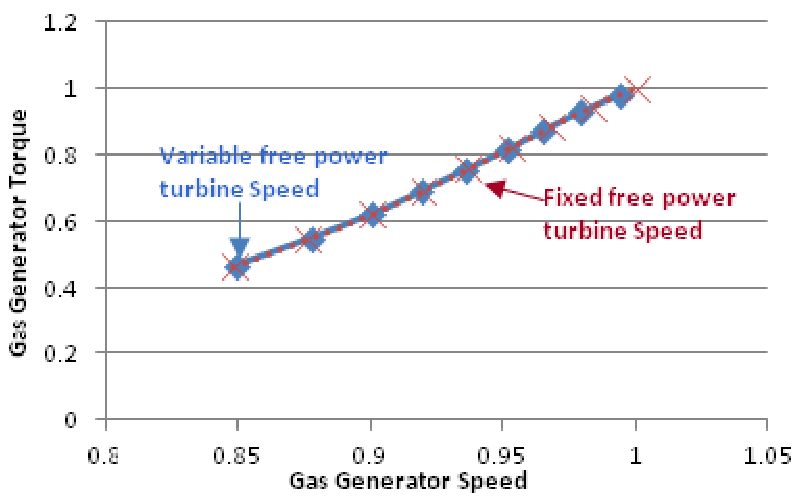

Fig. 15. Torque characteristics of gas generator for a twin-shaft gas turbine

The gas generator torque-speed characteristic for the twinshaft gas turbine is similar to that of a single shaft gas turbine running at variable speed operation, which also explains why the twin-shaft gas turbine gives relatively higher part-load efficiency. 


\section{CONCLUSION}

Variable speed operation has great benefit in improving part-load efficiency of a single-shaft gas turbine. It also provides better torque-speed characteristic for the reason that the compressor speed is adjusted to the power output. In contrast, the twin-shaft gas turbine doesn't benefit from variable speed operation as much as the single-shaft gas turbine because only the free power turbine itself benefits from the additional speed freedom - the gas generator already ordinarily operates at variable speed. Considering that two thirds of the power produced by the gas turbine is consumed by the compressor and the turbine itself operates in a relatively high efficiency range, improving only the efficiency of the free turbine doesn't contribute significantly to improve the whole twin-shaft gas turbine efficiency. But in general, the variable speed operation does improve the part-load efficiency especially for single-shaft gas turbines.

Future work will focus on the variable speed operation of gas turbines in dc power systems in particular, where generator speed and voltage are decoupled. In such dc power system, both generator and the converter are free to operate with variable turbine speed for better fuel efficiency.

\section{ACKNOWLEDGEMENTS}

The authors would like to thank Dr. Ruixian Fang for helpful discussions and access to GasTurb.

\section{REFERENCE}

[1] M. P. Boyce, Gas Turbine Engineering Handbook, $3^{\text {rd }}$ edition. Gulf Professional Publishing, 2006.

[2] T. Giampaolo, Gas Turbine Handbook Principles and Practices, $3^{\text {rd }}$ edition. Fairmont Press, 2006.

[3] J. H. Horlock, "Aero-engine derivative gas turbines for power generations: thermodynamic and economic perspectives," ASME Journal of Engineering for Gas Turbines and Power, vol. 119, pp. 119-123, 1997.

[4] N. zhang and R. Cai "Analytical solutions and typical characteristics of part-load performances of single-shaft gas turbine and its cogeneration," Energy Conversion and Management, vol. 43, pp. 1323-1337, 2002.

[5] F. Mura, R. W. De Doncker, B. Persigehl, P. Jeschke and K. Hameyer, "Analysis of a gearless medium-voltage variable speed gas turbine," $V G B$ PowerTech, vol. 91, No. 4, pp. 39-43, 2011.

[6] S. K. Yee, J. Milanvoic and F. M. Hughes, "Overview and comparative analysis of gas turbine models for system stability studies," IEEE Transactions on Power Systems, vol. 23, No. 1, pp. 108-118, Feb. 2008.

[7] L. N. Hannett, G. Jee and B Fardanesh, "A governor/turbine model for a twin-shaft combustion turbine," IEEE Transactions on Power Systems, vol. 10, No. 1, pp. 133-140, Feb. 1995.

[8] L. N. Hannett and A. Khan, "Combustion turbine dynamic model validation from tests," IEEE Transactions on Power Systems, vol. 8, No. 1, pp. 152-158, Feb. 1993.

[9] W. I. Rowen, "Simplified mathematical representations of heavey-duty gas turbines:" ASME Journal of Engineering for Power, vol. 105, pp. 865-869, Oct. 1983.

[10] P. Pourbeik and F. Modau, "Model development and field testing of a heavy-duty gas-turbine generator," IEEE Transactions on Power Systems, vol. 23, No. 2, pp. 664-672, May 2008.

[11] A. Lazzaretto and A. Toffolo, "Analytical and neural network models for gas turbine design and off-design simulation," Int. J. Applied Thermodynamics, vol. 4, No. 4, pp. 173-182, Dec. 2001

[12] Gas Turb, http://www.gasturb.de/

[13] S. Z. Vijlee, A. Ouroua, L. N. Domaschk and J. H. Beno, "Directly coupled gas turbine permanent magnet generator sets for prime power generation on board electric ships," Electric Ship Technologies Symposium, 2007, ESTS '07, IEEE, pp. 340-347, May 2007.
[14] H. Cohen, G. F. C. Rogers and H. I. H Saravanamuttoo, Gas Turbine Theory, $4^{\text {th }}$ edition. Addison-Wesley, 1996.

[15] J. H. kim, T. S. Kim, J. L. Sohn and S. T. Ro, "Comparative analysis of off-design performance characteristics of single and two shaft industrial gas turbines," Proceedings of ASME Turbo Expo, 2002.

[16] Cigre Task Force C4.02.25, Modeling of Gas turbines and Steam Turbines in Combined Cycle Power Plants, 2003.

[17] J. H. Horlock, Combined Power Plants Including Combined Cycle Gas Turbines (CCGT) Plants. New York: Pergamon, 1992.

[18] G. Crosa, F. Pittaluga, A. Trucco, F. Beltrami, A. Torelli and F. Traverso, "Heavy-duty gas turbine plant aerothermodynamic simulation using simulink," ASME Journal of Engineering for Gas Turbines and Power, vol. 120, pp. 550-556, 1998.

[19] M. T. Schobeiri, M. Attia and C. Lippke, "GETRAN: A generic, modelularlly structured computer code for simulation of dynamic behavior of aero- and power generation gas turbine engines," ASME Journal of Engineering for Gas Turbines and Power, vol. 116, pp. 483-494, 1994.

[20] J. H. Kim, T. W. Song, T. S. Kim and S. T. Ro, "Model development and simulation of transient behavior of heavy duty gas turbines," ASME Journal of Engineering for Gas Turbines and Power, vol. 123, pp. 589-594, 2001.

[21] O. O. Badmus, K. M. Eveker and C. N. Nett, "Control-oriented high frequency turbomachinery modeling: general one dimensional model development," ASME Journal of Turbomachinery, vol. 117, pp. 320-335, 1995.

[22] Working Group on Prime Mover and Energy Supply Models, "Dynamic models for combined cycle plants in power system studies," IEEE Transactions on Power Systems, vol. 9, No. 3, pp. 1698-1708, Aug. 1994.

[23] S. Suzaki, K. Kawata, M. Sekoguchi and M. Goto, "Mathematical model for a combined cycle plant and its implementation in an analogue power system simulator," IEEE Power Engineering Society Winter Meeting, Jan. 2000.

[24] M. Nagpal, A. Moshref, G. K. Morison and P. Kundur, "Experience with testing and modeling of gas turbines," IEEE Power Engineering Society General Meeting, Jan-Feb. 2001.

[25] L. Pereira, J. Undrill, D. Kosterev, D. Davies and S. Patterson, "A new thermal governor modeling approach in the WECC," IEEE Transactions on Power Systems, vol. 18, No. 2, pp. 819-829, May 2003.

[26] J. Undrill and A. Garmendia, "Modeling of combined cycle plants in grid simulation studies," IEEE Power Engineering Society General Meeting, Jan-Feb. 2001.

[27] L. Pereira "New thermal governor model development: its impact on operation and planning studies on the Western Interconnection," IEEE Power Energy Magazine, vol. 3, No. 3, pp. 62-70, May -Jun. 2005.

[28] L. Pereira, D. Kosterev, D. Davies and S. Patterson, "New thermal governor model selection and validation in WECC," IEEE Transactions on Power Systems, vol. 19, No. 1, pp. 517-523, Feb. 2004.

[29] P. Pourbeik, "Modeling of combined-cycle power plants for power system studies," IEEE Power Engineering Society General Meeting, Jul. 2003.

[30] K. Kunitomi, A. Kurita, H. Okamoto, Y. Tada, S. Ihara, P. Pourbeik and W. W. Price, "Modeling frequency dependency of gas turbine output," IEEE Power Engineering Society General Meeting, Jan-Feb. 2001.

[31] P. Pourbeik, The Dependence of Gas Turbine Power Output on System Frequency and Ambient Conditions, Cigre 38-101, 2002.

[32] A. Mirandola and A. Macor, "Full load and part load operation of gas turbine-steam turbine combined plant," ISEC, Vol. 8-15, 1986.

[33] A. Traverso, L. Magistri, A. F. Massardo, "Turbomachinery for the air management and energy recovery in fuel cell gas turbine hybrid systems," Energy, Vol 35, Issue 2, pp. 764-777, Feb. 2010.

[34] R. Roberts, J. Brouwer, F. jabbari, T. Junker and H. Ghezel-Ayagh, "Control design of an atmospheric solid oxide fuel cell/gas turbine hybrid system: variable versus fixed speed gas turbine operation," Journal of Power Sources, Vol. 161, Issue 1, pp. 484-491, Oct. 2006.

[35] J. Kurzke, “ The importance of component maps for gas turbine performance simulations," $12^{\text {th }}$ International Symposium on Transport Phenomena and Dynamics of Rotating Machinery, Hawai, Feb. 2008. 